\title{
Redescription of the tropical huntsman spider Olios lamarcki (Latreille, 1806) (Aranei: Sparassidae)
}

\section{Переописание тропического паука-спарассиды Olios lamarcki (Latreille, 1806) (Aranei: Sparassidae)}

\author{
John T.D. Caleb \\ Аэк.T.А. Калеб
}

Zoological Survey of India, Prani Vigyan Bhavan, M-Block, New Alipore, Kolkata - 700053 West Bengal, India.

E-mail: caleb87woodgate@gmail.com

KEY WORDS: diagnosis, taxonomy, Chennai, India.

КЛЮЧЕВЫЕ СЛОВА: диагноз, таксономия, Ченнаи, Индия.

ABSTRACT. Olios lamarcki (Latreille, 1806) is redescribed based on recently collected specimens from Chennai, Tamil Nadu, India. The internal structures of the female copulatory organs are illustrated in detail for the first time.

How to cite this article: Caleb J.T.D. 2018. Redescription of the tropical huntsman spider Olios lamarcki (Latreille, 1806) (Aranei: Sparassidae) // Arthropoda Selecta. Vol.27. No.4. P.339-343. doi: 10.15298/ arthsel. 27.4.10

РЕЗЮМЕ. Паук Olios lamarcki (Latreille, 1806) переописан по новому материалу из Ченнаи, штат Тамил-Наду, Индия. Впервые дано детальное описание внутренних структур копулятивных органов самки самки.

\section{Introduction}

The genus Olios was established by Walckenaer in 1837. It is the most speciose huntsman spider genus presently comprising 240 described species worldwide, of which 27 species are known from India [WSC, 2018]. Most of the species in the genus are known from their original descriptions only, but with a few exceptions warranting a thorough revision [Jäger, Otto, 2007]. The species, Olios lamarcki (Latreille, 1806) was relatively well-studied in India by some European arachnologists [Pocock, 1900; Gravely, 1931] because of its abundance in the tropics. But neither details of the male palp, nor the internal structure of the female copulatory organs are yet known. This paper is based on fresh material collected from the Bethel gardens, Vanianchatiram, Alamathi, Tamil Nadu, India. Both sexes of $O$. lamarcki are illustrated and redescribed in detail.

\section{Material and methods}

The specimens were hand-collected and preserved in $70 \%$ ethanol. They were later examined and photo- graphed by means of the Leica EZ4 HD stereomicroscope. All images were then processed with the aid of LAS core software (LAS EZ 3.0). The epigyne was dissected and cleared in $10 \% \mathrm{KOH}$. All measurements are in millimeters. Leg measurements are given as follows: total length (femur, patella, tibia, metatarsus, tarsus). Spination pattern follows Davies [1994]. The studied specimens have been deposited in the National Zoological Collections (NZC), Zoological Survey of India, Kolkata. Abbreviations: ALE - anterior lateral eye; AME - anterior median eye; LL - lateral lobe; PLE - posterior lateral eye; PME — posterior median eye; RTA — retrolateral tibial apophysis; TA — tegular apophysis.

\section{Taxonomy}

Family Sparassidae Bertkau, 1872

Genus Olios Walckenaer, 1837

Olios lamarcki (Latreille, 1806) Figs 1-17.

Thomisus lamarcki Latreille, 1806: 113 (description of $\sigma^{\top} \&$ \&). Olios captiosus Walckenaer, 1837: 565 (description of ${ }_{+}$); Vinson, 1863: 93, 304, pl.2, fig. 1 (description and illustration of + ).

Olios lamarcki Simon, 1880: 301; Karsch, 1892: 292, pl.11, fig. 14 (description and illustration of $\sigma^{7} \&$ ) ; Gravely, 1931: 241, figs. $5 \mathrm{~B}, 6 \mathrm{~B}-\mathrm{C}$ (description and illustration of $\sigma^{7} \&+$ ); Akash, Jahan, Badhon, 2017: 99, figs. 2a-c (description and illustration of ${ }^{+}$).

Eusparassus lamarcki Järvi, 1914: 60, 176, figs, 50, pl. 4, figs. 11-13 (Description and illustration of + ).

MATERIAL EXAMINED. 1 \% (ZSI-CDT-AA1103), 1 + (ZSICDT-AA1104) \& 1 subadult + (ZSI-CDT-AA1105), Bethel gardens, Vanianchatiram $\left(13.2160^{\circ} \mathrm{N}, 80.0985^{\circ} \mathrm{E}\right) 24 \mathrm{~m}$ a.s.1., Alamathi, India, leg. J. Daniel \& J.T.D. Caleb.

DIAGNOSIS. Medium sized to large spiders (total length female 20.2; male 13.5) (sensu Jäger, 2001). Based on the presence of the triangular, strongly pointed TA in the male palp, the species seems to be related to O. stimulator (Simon, 1897), O. suung Jäger, 2012 and O. digitatus Sun, Li et Zhang, 2011 (cf. Figs 5-6, 13-15 with figs 220 in Sethi \& Tikader, 1988, figs 10, 11 in Jäger, 2012 and figs 3, 4 in 

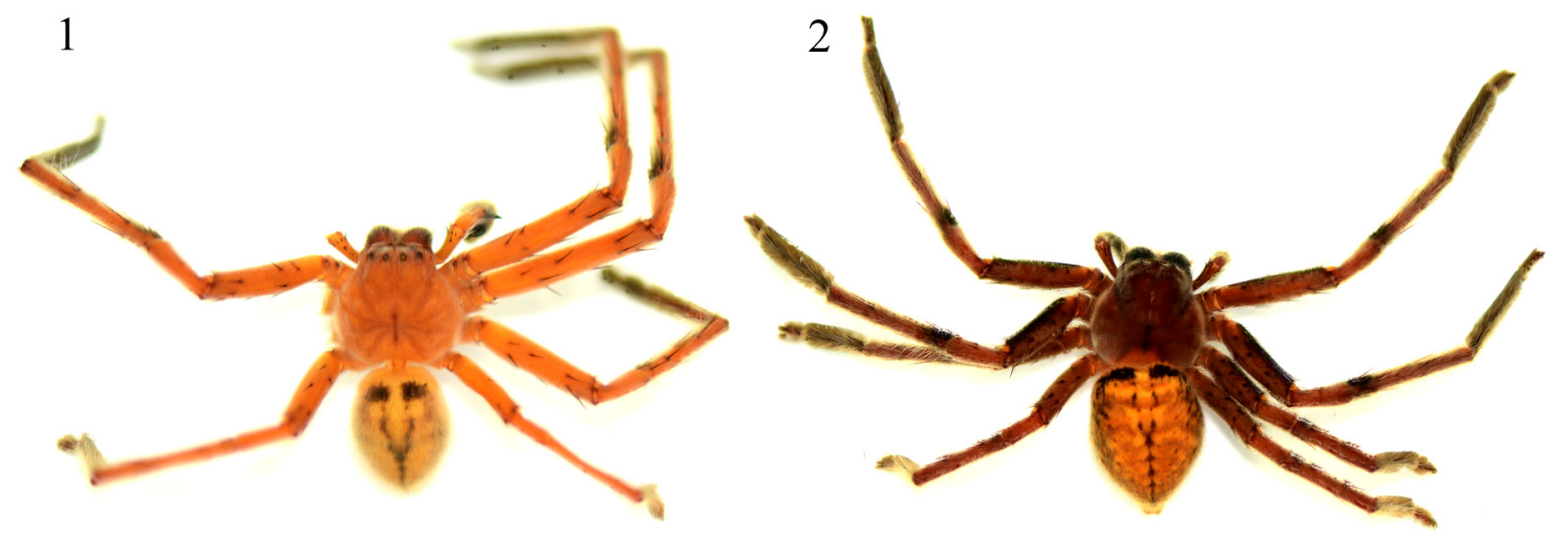

Figs 1-2. General habitus of Olios lamarcki (Latreille, 1806). 1 - male, dorsal view; 2 - female, dorsal view.

Рис. 1-2. Внешний вид Olios lamarcki (Latreille, 1806). 1 - самец, дорсально; 2 - самка, дорсально.

Sun, Li \& Zhang, 2011). O. lamarcki can be distinguished from the related species by the broad, simple embolus (distal portion spiraled and complex in $O$. suung): characteristic 'T-shaped' conductor; the triangular RTA, uniformly tapering toward its apex (constricted at the base and convex dorsally in $O$. stimulator). The females of $O$. stimulator, $O$. suung and $O$. digitatus are unknown yet. Based on the separated and posteriorly diverging LL, the female epigyne of $O$. lamarcki is similar to that of $O$. scalptor Jäger et Ono, 2001. It can be easily distinguished by the internal structures, for instance, by the oval membranous part (sub-quadrangular in $O$. scalptor), and the glandular part situated in the anterior region (cf. Figs 11, 17 with fig. 16 in Zhu \& Tso, 2006)

DESCRIPTION. MALE. Carapace length 6.73, width 6.77, anterior width 3.8. Abdomen length 6.8, width 5.3 . Leg formula: 2143; palp and leg measurements: Palp 9.6 $(3.2,0.9,2.0,-, 3.5)$, I $37.3(10.1,3.9,9.4,10.8,3.1)$, II $39.8(11.3,3.9,10.3,11.3,3.0)$, III 29.5 (9.2, 2.8, 7.4, 7.5, 2.6), IV $32.4(9.8,3.4,7.9,8.2,3.1)$. Spination: palp 0600, 0010, 1010, 0000; femur 3240, 3230, 3230, 1100; patella I 1000; tibia 3024, 3034, 3024, 2012; metatarsus I-II 2024, III 0024, IV 3014. Eye diameters: AME 0.41, ALE 0.36, PME 0.34, PLE 0.40; eye interdistances: AME-AME 0.28, AME-ALE 0.27, PME-PME 0.63, PME-PLE 0.79, AMEPME 0.50, ALE-PLE 0.33; clypeus AME 0.20, clypeus ALE 0.27. Chelicerae with two anterior and four posterior teeth, without denticles. Embolus crescent shaped, tapering toward the tip; conductor thick 'T-shaped', emerging from 1.30 o'clock position, light yellow in color; TA stout with wrinkled margins, distad, wide 'v-shaped' in retrolateral view; RTA thick and long (Figs 5-6, 13, 15). Coloration in ethanol (Figs 1, 3-4). Body and legs yellowish brown. Carapace with distinct brownish furrows converging at fovea. Chelicerae reddish brown. Sternum, maxillae and labium yellowish. Legs and palps yellowish, with darker metatarsi and tarsi. Abdomen with a distinct black pattern dorsally; a pair of large black spots present anteriorly with thin stripes converging medially and running as a single mid-dorsal stripe till the posterior end; faint brownish markings present along the lateral sides of the abdomen; a broad light brown median patch present ventrally.

FEMALE. Carapace length 8.82 , width 8.87 , anterior width 5.44; abdomen length 11.4, width 8.6. Leg formula:
2143; palp and leg measurements: Palp 11.1 (3.7, 1.1, 2.4,-, 3.9), I 39 (11.0, 4.1, 10.1, 10.6, 3.2), II 41.4 (12.2, 4.1, 10.9, 11.1, 3.1), III 30.2 (9.2, 3.1, 7.5, 7.6, 2.8), IV 33.2 (10.4, 3.0, 8.1, 8.5, 3.2). Spination: palp 0500, 0010, 1010, 2010; femur I-III 3230, IV 3210; patella II 1000; tibia 2024, 2034, 2024, 2024; metatarsus I-III 0024, IV 0034. Eye diameters: AME 0.52, ALE 0.45, PME 0.41, PLE 0.55; eye interdistances: AME-AME 0.42, AME-ALE 0.43, PME-PME 0.93, PME-PLE 0.96, AME-PME 0.70, ALE-PLE 0.47; clypeus AME 0.34, clypeus ALE 0.39. Chelicerae with two anterior, five (right) and four (left) posterior teeth, devoid of denticles (Fig 9). Epigyne with posteriorly diverging lateral ridges (Figs 10, 16). Copulatory openings (arrowed in Fig. 16) lead to the oval, membranous part having glandular parts on its anterior region; the internal duct system gently descends laterally, making a loop mid-way before ending posteriorly into the fertilization duct (Figs 11-12, 16-17). Coloration in ethanol (Figs 2, 7-9). Carapace without a distinct pattern, as in male; brown in color. Chelicerae dark brown. Sternum, maxillae and labium brown, with yellowish margins on the mouth parts. Legs and palps yellowish brown with darker metatarsi and tarsi. Abdomen yellowish, as in male; a broad black median patch present ventrally. 2018].

DISTRIBUTION. Madagascar to Sri Lanka, India [WSC,

NOTE. Mating plugs have been recorded in 17 species of Sparassids including four species of the genus Olios [Uhl et al., 2010]. It is recorded in O. lamarcki for the first time. Both of the female copulatory openings were found to be plugged with whitish, amorphous secretion (Fig. 10).

Acknowledgements. I am thankful to Dr Kailash Chandra, Director, Zoological Survey of India, Kolkata for providing necessary facilities. Thanks to Dr Vikas Kumar, Officer-in-Charge, Centre for DNA Taxonomy, Molecular Systematics Division, ZSI, Kolkata for his support. Mr. Job Daniel J.R., David, Samuel A.M. and Barnaba Thomas are thanked for their assistance during field collection. I am grateful to Dr. Peter Jäger (Senckenberg, Germany) for reviewing and providing constructive comments which greatly helped improve the manuscript. I gratefully acknowledge Dr Dmitri Logunov (Manchester, UK) and Dr Kirill Mikhailov (Moscow, Russia) for their editorial efforts in refining the $\mathrm{ms}$. 

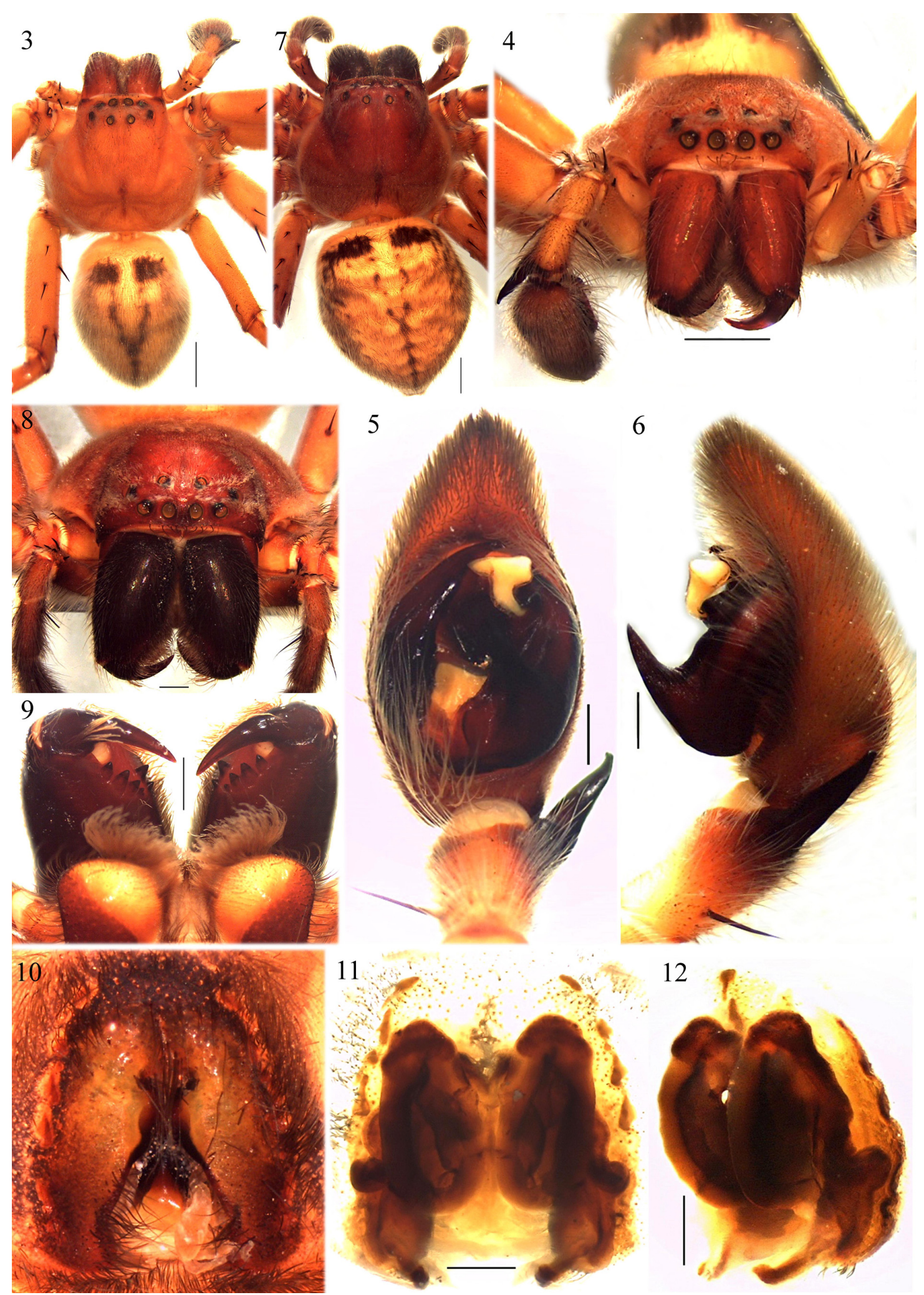

Figs 3-12. Morphology of Olios lamarcki (Latreille, 1806). 3 - male, dorsal view; 4 - same, front view; 5 - left male palp, ventral view; 6 - same, retrolateral view; 7 - female, dorsal view; 8 - front view; 9 - female chelicerae, ventral view; 10 - epigyne, ventral view; 11 - vulva, dorsal view; 12 - same, lateral view. Scale bars: $2 \mathrm{~mm}(3,7) ; 1 \mathrm{~mm}(4,8-9) ; 0.5 \mathrm{~mm}(5,6,10-12)$.

Рис. 3-12. Морфология Olios lamarcki (Latreille, 1806). 3 - самец, дорсально; 4 - самец, вид спереди; 5 - левая пальпа самца, вентрально; 6 - то же, ретролатерально; 7 - самка, дорсально; 8 - самка, вид спереди; 9 - хелицеры самки. вентрально; 10 - эпигина, вентрально; 11 - вульва, дорсально; 12 - вульва, вид сбоку. Масштаб: 2 мм (3, 7); 1 мм (4, 8-9); 0,5 мм (5, 6, 10-12). 

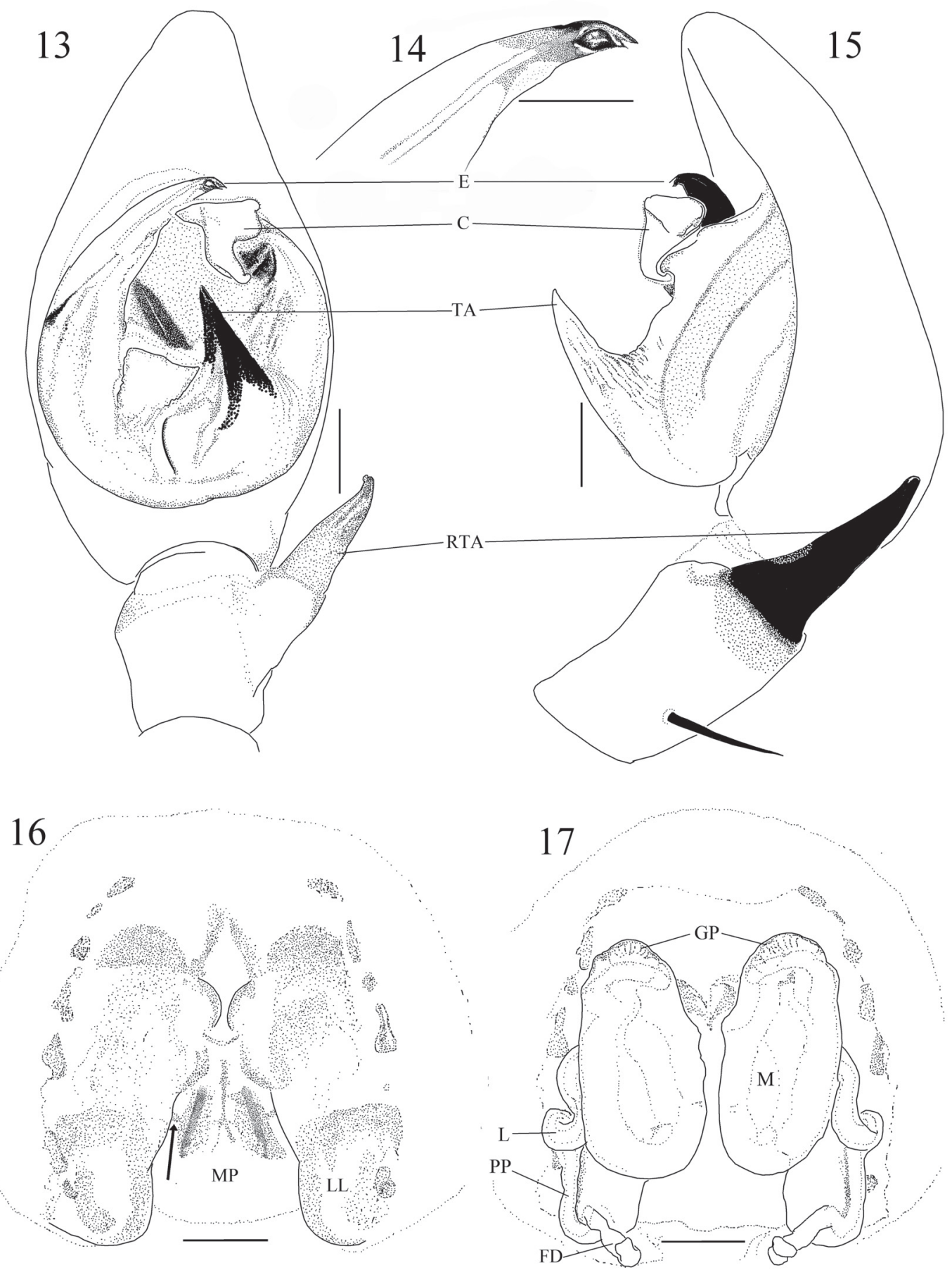

Figs 13-17. Copulatory organs of Olios lamarcki (Latreille, 1806). 13 - left male palp, ventral view; 14 - embolus, the upper half; 15 - left male palp, retrolateral view; 16 - epigyne, ventral view; 17 - spermathecae, dorsal view. Abbreviations: $\mathrm{C}$ - conductor; E embolus; FD - fertilization duct; GP - glandular part; L — lumen; LL — lateral lobe; M - membranous part of the internal duct system; MP - median plate; PP — posterior part of the internal duct system; RTA — retrolateral tibial apophysis; TA — tegular apophysis; arrow indicates the copulatory opening. Scale bars: $0.5 \mathrm{~mm}(13,15-17) ; 0.25 \mathrm{~mm}(14)$.

Рис. 13-17. Копулятивные органы Olios lamarcki (Latreille, 1806). 13 - левая пальпа самца, вентрально; 14 - эмболюс, верхняя половина; 15 - левая пальпа самца, ретролатерально; 16 - эпигина, вентрально; 17 - сперматека, дорсально. Сокращения: C - кондуктор; Е - эмболюс; FD - осеменительный канал; GP - железистый канал; L — просвет; LL — латеральная лопасть; M - мембранизированная часть внутренних канальцев; MP - медиальная пластинка; PP — задняя часть внутренних канальцев; RTA - ретролатеральный вырост голени; ТА — вырост тегулума; стрелкой показано копуляторное отверстие. Масштаб: 0,5 мм (13, 15-17); 0,25 мм (14). 


\section{References}

Akash M., Jahan N., Badhon M.K. 2017. Occurrence of a huntsman spider Olios lamarcki Latreille, 1806 (Araneae: Araneomorphae: Sparassidae) from Nijhum dwip, Bangladesh // Bangladesh Journal of Zoology. Vol. 45. No.1. P.97-100. doi:10. 3329/bjz.v45i1.34199.

Davies V.T. 1994. The huntsman spiders Heteropoda Latreille and Yiinthi gen. nov. (Araneae: Heteropodidae) in Australia // Memoirs of the Queensland Museum. Vol.35. P.75-122.

Gravely F.H. 1931. Some Indian spiders of the families Ctenidae, Sparassidae, Selenopidae and Clubionidae // Records of the Indian Museum, Calcutta. Vol.33. P.211-282.

Jäger P. 2001. Diversität der Riesenkrabbenspinnen im Himalaya - die Radiation zweier Gattungen in den Schneetropen (Araneae, Sparassidae, Heteropodinae) // Courier Forschungsinstitut Senckenberg. Vol.232. S.1-136.

Jäger P., Ono H. 2001. First records of the genera Pseudopoda, Sinopoda, and Olios from Taiwan with descriptions of four new species (Araneae: Sparassidae) // Acta Arachnologica. Vol.50. No.1. P.21-29.

Jäger P., Otto S. 2007. New records of Olios sericeus (Kroneberg 1875 ) with notes on its taxonomy and biogeography (Araneae: Sparassidae: Sparassinae) // Revista Ibérica de Aracnología. Vol.14. P.19-24.

Jäger P. 2012. New species of the spider genus Olios Walckenaer, 1837 (Araneae: Sparassidae: Sparassinae) from Laos // Zootaxa. Vol.3228. P.61-68.

Järvi T.H. 1914. Das Vaginalsystem der Sparassiden. II. Spezieller Teil // Annales Academiae Scientiarum Fennicae (A). Vol.4 S.118-235.
Karsch F. 1892. Arachniden von Ceylon und von Minikoy gesammelt von den Herren Doctoren P. und F. Sarasin // Berliner Entomologische Zeitschrift. Bd.36. S.267-310.

Latreille P.A. 1806. Genera crustaceorum et insectorum. Paris, tome Vol.1. 302 p. (Araneae, pp 82-127).

Pocock R.I. 1900. The fauna of British India, including Ceylon and Burma. Arachnida. London. 279 p.

Sethi V.D., Tikader B.K. 1988. Studies on some giant crab spiders of the family Heteropodidae from India // Records of the Zoological Survey of India, Miscellaneous Publications, Occasional Paper. Vol.93. P.1-94.

Sun C.K., Li X.H., Zhang F. 2011. A new species of the genus Olios (Araneae: Sparassidae) from Hainan Island, China // Acta Arachnologica Sinica. Vol.20. No.2. P.88-90.

Uhl G., Nessler S.H., Schneider, J.M. 2010 Securing paternity in spiders? A review on occurrence and effects of mating plugs and male genital mutilation // Genetica. Vol.138. P.75-104. doi: 10.1007/s10709-009-9388-5.

Vinson A. 1863. Aranéides des îles de la Réunion, Maurice et Madagascar. Paris. cxx, 337 p.

Walckenaer C.A. 1837. Histoire naturelle des insectes. Aptères. Paris. Vol.1. 682 p.

WSC 2018. World Spider Catalog. Natural History Museum Bern; online at: http://wsc.nmbe.ch, version 19.5 (accessed on 25 July 2018).

Zhu M.S., Tso, I.M. 2006. Two new species of the family Sparassidae from Taiwan, with description of the female of Olios scalptor (Arachnida: Araneae) // Bulletin of the British Arachnological Society. Vol.13. Pt.7. P.267-270.

Responsible editors D.V. Logunov, K.G. Mikhailov 